\title{
Penerapan Persamaan Diferensial Verhulst dalam Menentukan Proyeksi Penduduk di Kabupaten Tulungagung
}

\author{
Dewi Anggreini \\ Program Studi Pendidikan Matematika STKIP PGRI Tulungagung, \\ Jl. Mayor Sujadi Timur No.7 Plosokandang Kedungwaru Tulungagung Jawa Timur, Indonesia
}

Korespondensi; Email: anggreini_004@yahoo.com

\begin{abstract}
Abstrak
Penelitian ini bertujuan menentukan proyeksi pertumbuhan penduduk di Kabupaten Tulungagung provinsi Jawa Timur dengan model persamaan diferensial Verhulst berdasarkan laju pertumbuhan dan daya tampung (carrying capacity). Target khusus dari hasil penelitian ini adalah model pertumbuhan logistik bisa digunakan sebagai alat untuk mengetahui proyeksi pertumbuhan penduduk berdasarkan laju pertumbuhan dan daya tampung dibeberapa daerah di Indonesia. Metode riset yang digunakan pada tahap pertama adalah menentukan subjek penelitian dan tahap Kedua adalah (1) mengumpulkan data penelitian (2) analisis data dan terakhir menarik kesimpulan. Data penelitian ini diperoleh dari BPS Kabupaten Tulungagung yaitu jumlah penduduk dari tahun 2010-2016. Hasil Penelitian menunjukkan bahwa: 1) Besarnya nilai carrying capacity yang membatasi penduduk di Kabupaten Tulungagung adalah sebesar 1.089.103,3. 2) Laju pertumbuhan intrinsik penduduk di kabupaten Tulungagung dengan menggunakan Model pertumbuhan logistik adalah sebesar $r=0,07480$. 3) Jumlah penduduk di Kabupaten Tulungagung pada tahun 2025 dari hasil estimasi menggunakan model pertumbuhan logistik adalah sebesar 1.055.578 jiwa. 4) Proyeksi jumlah penduduk di Kabupaten Tulungagung lebih tepat menggunakan model logistik I dengan persamaannya $N=\frac{1.089 .103,3}{(0,09754) e^{-(0,07480) t}+1}$. Penelitian ini diharapkan dapat bermanfaat bagi semua pihak khususnya pada bidang matematika terapan serta metode dalam menghitung pertumbuhan populasi di suatu daerah pada periode yang akan datang.
\end{abstract}

Kata Kunci: carrying capacity, laju pertumbuhan; model logistik

\begin{abstract}
This study aims to determine the projected population growth in Tulungagung Regency of East Java province with a model of Verhulst differential equations based on growth rate and carrying capacity. The specific target of this research is logistic growth model can be used as a tool to know the projection of population growth based on growth rate and capacity in some regions in Indonesia. Research methods used in the first stage is to determine the subject of research and the second stage is (1) collect research data (2) data analysis and last draw conclusions. The data of this research is obtained from BPS of Tulungagung Regency that is population from 2010-2016. The results showed that: 1) The amount of carrying capacity that limits the population in Tulungagung Regency is equal 1.089.103,3. 2) The intrinsic growth rate of the population in Tulungagung district using the logistic growth model is $r=0,074803$ 3) The population in Tulungagung District in 2025 from the estimation using the logistic growth model is 1.055.578 soul, 4) The projection of population in Tulungagung is more appropriate using the logistic model I with the equation $\mathrm{N}=\frac{1.089 .103,3}{(0,09754) \mathrm{e}^{-(0,07480) t}+1}$. This study is expected to be useful for all parties, especially in the field of applied mathematics and methods in calculating population growth in an area in the period to come.
\end{abstract}

Keywords: carrying capacity; growth rate; logistic models

\section{Pendahuluan}

Proyeksi kependudukan sejak lama telah menjadi masalah penting di dunia. Populasi ukuran dan pertumbuhan di suatu negara secara langsung mempengaruhi situasi ekonomi, kebijakan, budaya, 
pendidikan dan biaya sumber daya alam. Proyeksi penduduk bukan merupakan ramalan jumlah penduduk tetapi suatu perhitungan ilmiah yang didasarkan pada asumsi dari komponen-komponen laju pertumbuhan penduduk, yaitu kelahiran, kematian, dan perpindahan. Ketiga komponen inilah yang menentukan besarnya jumlah penduduk dan struktur umur penduduk di masa yang akan datang. Untuk menentukan masing-masing asumsi diperlukan data yang menggambarkan tren di masa lampau hingga saat ini, faktor-faktor yang mempengaruhi komponen-komponen itu, dan hubungan antara satu komponen dengan yang lain serta target yang diharapkan tercapai pada masa yang akan datang.

Tulungagung adalah sebuah Kabupaten yang sangat terkenal dengan sebutan kota marmer. Dengan jumlah penduduk sebanyak 1.026.101 jiwa (data BPS tahun 2016) dan kepadatan penduduk sejumlah $972 \mathrm{jiwa} / \mathrm{km} 2$. Luas Wilayah Kabupaten Tulungagung sebesar 1.055,65 Km²[1]. Dari beberapa informasi di atas alasan peneliti memilih Kabupaten Tulungagung tersebut adalah: pertama, dikarenakan belum adanya penelitian sebelumnya yang membahas tentang pertumbuhan dan proyeksi penduduk di Kabupaten Tulungagung dengan menggunakan persamaan logistik. Alasan kedua yaitu Kabupaten Tulungagung memiliki daerah yang tidak luas dibandingkan Kabupaten disekitarnya akan tetapi, jumlah penduduknya jauh lebih banyak dibandingkan dengan jumlah penduduk di Kabupaten sekitarnya. Dari hal tersebut sangat menarik peneliti untuk dilakukan penelitian lebih lanjut.

Model-model pertumbuhan populasi yang dijelaskan terdahulu bersifat hipotetik (proses kelahiran murni) dengan asumsi yang tidak realistis antara lain bahwa makanan yang tersedia tidak terbatas dan individu yang dilahirkan tidak pernah mati. Asumsi-asumsi ini diperbaiki dengan memasuki keadaan yang lebih realistis. Model pertumbuhan populasi klasik mengasumsikan bahwa laju pertumbuhan populasi terhadap waktu berbanding lurus dengan jumlah populasi yang ada [12]. Pertumbuhan populasi merupakan salah satu contoh penerapan persamaan diferensial dalam bidang Biologi. Dalam Ekologi pertumbuhan populasi sering disebut sebagai, "dinamika populasi". [12].

Model pertumbuhan logistik adalah model pertumbuhan yang dibatasi oleh suatu faktor penghambat. Tujuan penelitian ini yaitu menghitung carrying capacity, laju pertumbuhan penduduk, jumlah penduduk kemudian dicari proyeksi jumlah penduduk di Kabupaten Tulungagung dan Trenggalek Provinsi Jawa Timur untuk waktu yang akan datang menggunakan program Excel dan MAPLE. Berdasarkan penjelasan-penjelasan di atas, maka dari itu dipilih judul penelitian, Penerapan Persamaan Diferensial Verhulst dalam Menentukan Proyeksi Penduduk di Kabupaten Tulungagung .

Dari pemaparan di atas peneliti mengambil rumusan masalah sebagai berikut 1) Bagaimana menentukan besarnya nilai carrying capacity yang membatasi penduduk di Kabupaten Tulungagung ? 2) Bagaimana menentukan laju pertumbuhan penduduk dengan menggunakan Model pertumbuhan logistik? 3) Bagaimana menghitung jumlah penduduk di Kabupaten Tulungagung pada tahun 2025 dari hasil estimasi menggunakan model pertumbuhan logistik? 4) Bagaimana menentukan proyeksi jumlah penduduk di Kabupaten Tulungagung menggunakan model pertumbuhan logistik?. Dari rumusan masalah tersebut dapat dijadikan dasar tujuan penelitian diantaranya 1) menentukan laju pertumbuhan penduduk dengan menggunakan model pertumbuhan logistik. 2) Menentukan jumlah penduduk di Kabupaten Tulungagung pada tahun 2025 dari hasil estimasi menggunakan model pertumbuhan logistik. 3) Menentukan proyeksi jumlah penduduk di Kabupaten Tulungagung menggunakan model pertumbuhan logistik.

\section{Landasan Teori}

\section{Model Pertumbuhan Logistik}

Pada model pertumbuhan logistik diasumsikan bahwa rata-rata total pertumbuhan tergantung pada ukuran populasi (model linear) atau sama dengan laju pertumbuhan perkapita [2]. Model pertumbuhan logistik adalah model pertumbuhan yang memperhitungkan faktor logistik berupa ketersediaan makanan dan ruang hidup. Model ini mengasumsikan bahwa pada waktu tertentu jumlah populasi akan mendekati titik kesetimbangan (equilibrium).

Persamaan logistik disusun berdasarkan asumsi asumsi yaitu populasi akan mencari keseimbangan dengan lingkungan sehingga memiliki sebaran umur stabil (stable age distribution) [12]. Populasi memiliki laju pertumbuhan yang secara berangsur-angsur menurut secara tetap dengan konstanta $r$. Pengaruh $r$ terhadap peningkatan kerapatan karena bertumbuhnya populasi merupakan respon yang instaneous atau seketika itu juga dan tidak terdapat penundaan atau senjang waktu (time lag). Sepanjang 
waktu pertumbuhan keadaan lingkungan tidak berubah. Pengaruh kerapatan adalah sama tehadap semua tingkat umur populasi. Peluang untuk berkembang biak tidak dipengaruhi oleh kerapatan. Sesuai dengan penurunan rumus menentukan carrying capacity. Model logistik yang digunakan pada penelitian ini adalah

$$
N(t)=\frac{K}{e^{-r t}\left(\frac{K}{N_{0}}-1\right)+1}
$$

dengan $K$ diperoleh dari

$$
\lim _{t \rightarrow \infty} N(t)=\frac{a}{b}=\frac{N_{1}\left(2 N_{0} N_{2}-N_{2} N_{1}-N_{0} N_{1}\right)}{N_{0} N_{2}-N_{1}^{2}}
$$

\section{Fungsi}

\section{Definisi 1 [11]}

Diketahui $R$ relasi dari $A$ ke $B$. Apabila setiap $x \in A$ berelasi $R$ dengan tepat satu $y \in B$ maka $R$ disebut fungsi dari $A$ ke $B$. Jadi, relasi $R$ dari $A$ ke $B$ disebut fungsi jika untuk setiap $x \in A$ terdapat tepat satu $y \in B$ sehingga $b=R(a)$. Selanjutnya apabila $f$ merupakan fungsi dari himpunan $A$ ke himpunan $B$, maka dituliskan $f: A \rightarrow B$. Dalam hal ini himpunan $A$ dinamakan domain atau daerah definisi atau daerah asal, sedangkan himpunan $B$ dinamakan kodomain atau daerah kawan fungsi $f$.

\section{Limit}

Definisi 2.a [11]

Limit $f(x) x$ mendekati $c$ sama dengan $L$, ditulis:

$$
\lim _{x \rightarrow c} f(x)=L
$$

Jika untuk setiap $x$ yang cukup dekat dengan $c$, tetapi $x \neq c$, maka $f(x)$ mendekati $L$.

Secara matematis definisi diatas dapat ditulis sebagai berikut: $\lim _{x \rightarrow c} f(x)=L$ jika untuk setiap bilangan $\epsilon>0$ yang diberikan (berapapun kecilnya) terdapat bilangan $\delta>0$ sehingga untuk setiap $x \in D_{f}$ dengan $0<|x-c|<\delta$ berlaku $|f(x)-L|<\varepsilon$.

Definisi 2.b [9]

$\lim _{x \rightarrow a} f(x)=L$, dikatakan limit dari $f(x)$, ketika $x$ mendekati $a$, sama dengan $L$ jika kita dapat membuat nilai dari $f(x)$ secara sembarang mendekati $L$ (sedekat yang kita inginkan) dengan mengambil nilai $x$ cukup dekat dengan $a$ (pada kedua sisi $a$ ), tetapi tidak sama dengan $a$.

\section{Turunan}

Definisi 3 [9]

Diberikan fungsi $f$ dan $a \in D_{f}$. Turunan fungsi $f$ di $a$, dinyatakan dengan $f^{\prime}(a)$ dan didefinisikan dengan:

$$
f^{\prime}(a)=\lim _{h \rightarrow 0} \frac{f(a+h)-f(a)}{h}
$$

Asalkan limit ini ada.

Berdasarkan definisi 3 diatas jika ditulis $x=a+h$ maka $x$ mendekati $a$ jika dan hanya jika $h$ mendekati 0 . Oleh karena itu dapat pula ditulis: 


$$
f^{\prime}(a)=\lim _{x \rightarrow a} \frac{f(x)-f(a)}{x-a}
$$

Jika $f^{\prime}(a)$ ada maka $f$ dikatakan mempunyai turunan atau diferensiabel di $a$.

\section{Persamaan Diferensial}

Definisi 4.a [8]

Persamaan diferensial adalah suatu persamaan yang memuat satu atau lebih turunan dari suatu fungsi yang tak diketahui. Suatu persamaan diferensial yang berorde $n$ dapat ditulis dalam bentuk:

$$
F\left(x, y, y^{\prime}, y^{\prime \prime}, \ldots, y^{(n)}=0\right.
$$

Dengan $y^{(n)}$ melambangkan turunan ke $n$ dari $y$ terhadap $x$. Kasus khusus apabila $F$ suatu fungsi linear dari $y^{\prime}, y^{\prime \prime}, \ldots, y^{(n)}$.

Definisi 4.b [8]

Persamaan Diferensial yang dapat ditulis dalam bentuk

$$
a_{0}(x) y^{(n)}+a_{1}(x) y^{(n-1)}+\cdots+a_{n}(x) y=F(x)
$$

Dengan $a_{0}, a_{1}, \ldots, a_{n}$ dan $F$ fungsi-fungsi dari $x$ saja dan $a_{0}(x) \neq 0$ dinamakan persamaan diferensial linear orde $n$. Persamaan tersebut linear dalam $y^{\prime}, y^{\prime \prime}, \ldots, y^{(n)}$.

Definisi 4.c [4]

Suatu persamaan diferensial biasa orde $n$ adalah persamaan yang dapat ditulis dalam bentuk

$$
y^{(n)}=F\left(x, y, y^{\prime}, \ldots, y^{(n-1)}\right)
$$

dimana $y, y^{\prime}, \ldots, y^{(n)}$ semua ditentukan nilainya oleh $x$.

\section{Persamaan diferensial Linear Orde Satu}

Persamaan diferensial dengan bentuk $\frac{d y}{d x}+P y=Q$ (Purcell, 1987: 434) dengan $P$ dan $Q$ adalah fungsi $x$ saja, disebut persamaan Diferensial Orde Satu.Suatu persamaan jenis ini dalam prinsip selalu dapat diselesaikan. Pertama mengalikan kedua ruas dengan faktor integral $S . \quad S=e^{\int p(x) d x}$, yang menghasilkan $e^{\int p(x) d(x)} \frac{d y}{d x}+e^{\int p(x) d x} P(x) y=Q(x) e^{\int p(x) d x}$. Kemudian kenali ruas kiri sebagai turunan dari $y e^{\int p(x) d x}$, sehingga persamaan membentuk $\frac{d}{d x}\left(y e^{\int p(x) d x}\right)=Q(x) e^{\int p(x) d x}$.

Pengintegralan kedua ruas menghasilkan $y e^{\int p(x) d x}=\int\left(Q(x) e^{\int p(x) d x}\right) d x$. Sehingga $y=e^{-\int p(x) d x} \int\left(Q(x) e^{\int p(x) d x}\right) d x$.

\section{Turunan $\boldsymbol{e}^{\boldsymbol{x}}$ [5]}

Dikarenakan exp dan In adalah fungsi-fungsi balikkan, maka fungsi $\exp x=e^{x}$ dapat diturunkan. Andaikan $y=e^{x}$, maka: $x=\ln y$. Ruas kanan dan kiri diturunkan menurut $\mathrm{x}$, diperoleh $1=\frac{1}{y} D_{x} y$ (aturan rantai). Sehingga $D_{x} y=y=e^{x}$. Turunan $e^{x}$ adalah juga $e^{x}$.Jadi $D_{x} e^{x}=e^{x}$. Apabila $u=$ $f(x)$, dapat diturunkan, maka menurut aturan rantai: $D_{x} e^{u}=e^{u} D_{x} u$. Rumus $D_{x} e^{x}=e^{x}$ dapat menghasilkan rumus $\int e^{x} d x=e^{x}+c$, atau apabila $x$ diganti dengan $\mathrm{u}$ maka diperoleh: $\int e^{u} d u=e^{u}+c$. 


\section{Metode Penelitian}

\section{Tahapan Penelitian}

Metode riset yang digunakan pada penelitian ini yaitu: Tahap pertama adalah menentukan subjek penelitian, adapun subjek penelitiannya adalah jumlah penduduk mulai tahun 2010 sampai tahun 2016 di Kabupaten Tulungagung Provinsi Jawa Timur dan Tahap Kedua adalah (1) mengumpulkan data penelitian, adapun pengumpulan data penelitian didapatkan dari data sekunder di Badan Pusat Statistik Kabupaten Tulungagung Provinsi Jawa Timur (2) analisis data dan terakhir menarik kesimpulan.

\section{Lokasi Penelitian}

Lokasi penelitian ini adalah Badan Pusat Statistik (BPS) Kabupaten Tulungagung Provinsi Jawa Timur.

\section{Peubah yang diamati}

Peubah yang diamati dalam penelitian ini adalah laju pertumbuhan intrinsik dan jumlah populasi penduduk pada waktu t. Laju pertumbuhan intrinsik atau intrinsic growth rate adalah nilai yang menggambarkan daya tumbuh suatu populasi. Dapat dikatakan bahwa laju pertumbuhan intrinsik adalah kemampuan tumbuh populasi yang disebabkan oleh daya dukung lingkungan sehingga merupakan fungsi terhadap waktu.Dalam hal ini diasumsikan laju pertumbuhan intrinsik bernilai positif $(r>0)$, yaitu mengingat setiap populasi memiliki potensi untuk berkembang biak. Model pertumbuhan dapat diturunkan dengan menggunakan asumsi: (a) laju pertumbuhan populasi $\frac{1}{N} \frac{d N}{d t}$ pada saat $N=0$ adalah $r$ (b) laju pertumbuhan ini menurun secara linear dan bernilai 0 saat $N=K$.

\section{Model yang digunakan}

Pada Model pertumbuhan logistik (logistic growth mode/) menggunakan kaidah logistik (logistic law) bahwa persediaan logistik ada batasnya. Model ini mengasumsikan bahwa pada masa tertentu jumlah populasi akan mendekati titik kesetimbangan (equilibrium) [6]. Pada titik ini jumlah kelahiran dan kematian dianggap sama, sehingga grafiknya akan mendekati konstan (zero growth). Dari asumsi tersebut dapat diturunkan suatu model pertumbuhan populasi yang disebut sebagai model pertumbuhan logistik. Dari asumsi tersebut diturunkan sebuah model pertumbuhan populasi yang disebut sebagai model pertumbuhan logistik, yaitu: $\frac{1}{N} \frac{d N}{d t}=r-\frac{r}{K} N$ atau $\frac{d N}{d t}=r N\left(1-\frac{N}{K}\right)$.

\section{Rancangan Penelitian}

Pendekatan yang digunakan dalam penelitian ini adalah pendekatan kualitatif. Metode penelitian kualitatif adalah metode penelitian yang berlandaskan pada filsafat postpositivisme, digunakan untuk meneliti pada kondisi objek yang alamiah, dimana peneliti sebagai instrument kunci, teknik pengumpulan data dilakukan secara triangulasi (gabungan), analisis data bersifat induktif/kualitatif, dan hasil penelitian kualitatif lebih menekankan makna daripada generalisasi [10]. Penelitian kualitatif adalah penelitian yang bermaksud untuk memahami fenomena tentang apa yang dialami oleh subjek penelitian [7]. Jenis penelitian ini termasuk penelitian Deskriptif. Sedangkan bentuk rancangan penelitian ini adalah studi kasus.

Rancangan studi kasus merupakan salah satu jenis pendekatan kualitatif yang menelaah sebuah kasus tertentu dalam konteks atau setting kehidupan nyata kontemporer [3]. Kasus kasus dibatasi oleh waktu dan aktivitas, dan peneliti mengumpulkan informasi secara lengkap dengan menggunakan berbagai prosedur pengumpulan data berdasarkan waktu yang telah ditentukan. Perlakuan yang akan diberikan terhadap data yaitu penerapan persamaan differensial Verhulst/logistik berdasarkan carrying capacity menggunakan Aplikasi Microsoft Excel dan MAPLE.

\section{Teknik Pengumpulan Data}

Data yang digunakan dalam penelitian ini hanya ada satu jenis, yaitu data sekunder. Data sekunder dikumpulkan dari beberapa sumber, diantaranya adalah data jumlah penduduk diambil dari Badan Pusat Statistik (BPS) Kabupaten Tulungagung mulai tahun 2010 sampai tahun 2016. Adapun kenapa dipilih mulai dari tahun 2010, dikarenakan sesuai dengan laporan data BPS Pusat Jakarta bahwa mulai tahun 2010 jumlah penduduk Indonesia masuk dalam jumlah penduduk terbesar ke 4 di dunia. Adapun 
untuk tahun 2016 dikarenakan data sekunder tersebut merupakan data yang paling baru disajikan oleh Badan Pusat Statistik (BPS) di Kabupaten Tulungagung.

\section{Teknik Analisis Data}

Tehnik yang digunakan dalam menganalisis bentuk dan model penelitian ini adalah sebagai berikut: a) Mengkonstruksi model persamaan diferensial verhulst/logistik. b) Mencari solusi dari persamaan diferensial $\frac{d N}{d t}=r N\left(1-\frac{N}{K}\right)$. c) Menentukan waktu yang diukur dan jumlah populasi awal serta populasi pada tahun selanjutnya dimisalkan saat $t=0$ yaitu $N_{0}$, saat $t=1$ yaitu $N_{1}$ dan saat $t=2$ yaitu $N_{2}$. d) Menentukan kapasitas tampung (carrying capacity). e) Mencari laju pertumbuhan penduduk yaitu ratau intrinsic growth rate menggunakan solusi model persamaan logistik. f) Menghitumg jumlah penduduk di Kabupaten Tulungagung dengan solusi persamaan logistik. g) Menentukan proyeksi jumlah penduduk di Kabupaten Tulungagung menggunakan model pertumbuhan logistik yang nilainya cukup mendekati hasil sensus. h) Menentukan proyeksi penduduk di Kabupaten Tulungagung dengan aplikasi Microsoft Excel dan MAPLE.

\section{Hasil dan Pembahasan}

\section{Model Pertumbuhan Eksponensial}

Beberapa asumsi yang digunakan dalam pendugaan pertumbuhan penduduk secara eksponensial, yaitu: Laju kelahiran dan kematian konstan, Tidak ada struktur genetik, Tidak ada struktur perbedaan umur dan ukuran, Tidak ada waktu tunda. Pada model ini diasumsikan bahwa populasi bertambah dengan laju pertumbuhan populasi yang sebanding dengan besarnya populasi. Misalkan $N(t)$ menyatakan jumlah populasi pada saat $t$ (waktu), dan $k$ menyatakan laju pertumbuhan populasi maka model populasi eksponensial dinyatakan dalam bentuk: [13]

$$
\frac{d N}{d t}=r N(t) \quad \text { atau } \quad \frac{d N_{t}}{N_{t} d t}=r N(t)
$$

Dimana:

$N_{t}$ : Kerapatan populasi atau banyaknya populasi pada waktu $t$ jam

$N_{0}$ : Kerapatan populasi atau banyaknya populasi mula-mula

$r \quad$ : Laju pertumbuhan populasi

$t \quad$ : Waktu ke $t$ (jam)

Persamaan logistik disusun berdasarkan asumsi-asumsi antara lain: 1) Populasi akan mencapai keseimbangan dengan lingkungan sehingga memiliki sebaran umur stabil (stable age distribution). 2) Populasi memiliki laju pertumbuhan yang secara berangsur-angsur menurun secara tetap dengan konstanta $r$. 3) Pengaruh $r$ terhadap peningkatan kerapatan karena bertumbuhnya populasi merupakan respon yang instantaneous atau seketika itu juga dan tidak terdapat penundaan atau senjang waktu (time lag) sepanjang waktu pertumbuhan keadaan lingkungan tidak berubah. 4) Pengaruh kerapatan adalah sama terhadap semua tingkat umur populasi. 5) Peluang untuk berkembang biak tidak dipengaruhi oleh kerapatan [12].

Dengan perjalanan waktu, $N$ tumbuh semakin besar sehingga persaingan antar individu dalam populasi (ruang, makanan, dan sebagainya) semakin meningkat pula dan pertumbuhan populasi semakin terhambat. Hal ini mengakibatkan $\frac{d N}{d t}$ semakin menurun dan berhenti tumbuh $(r=0)$ pada saat daya dukung dicapai. Untuk mengakomodasi faktor berkurangnya daya dukung akibat pertumbuhan, model Malthus $\frac{d N}{d t}=r N(t)$ perlu dimodifikasi. Modifikasi model Malthus dilakukan karena Model Malthus yang naik terus itu jelas tidak sesuai bila diambil cukup besar. Bila $N$ menjadi besar tempatnya terbatas maka timbul hambatan karena padatnya populasi yang akan mengurangi populasinya. Diasumsikan bahwa $f(N)$ adalah fungsi linear dimana a merupakan faktor penurunan proporsional [12]. 


$$
\begin{aligned}
f(N) & =r-a N, r, a>0, N>0 \\
\frac{d N}{N d t} & =r-a N
\end{aligned}
$$

Persamaan ini disebut sebagai model logistik atau model Verhulst-pearl. Model persamaan diferensial $\frac{d N}{d t}=r N(t)$ merupakan persamaan diferensial separabel, sehingga kita dapat mencari solusi umumnya sebagai berikut:

$$
\begin{aligned}
\int \frac{d N}{N} & =\int r d t \\
e^{\ln N(t)} & =e^{r t+c} \\
N(t) & =e^{r t+c}
\end{aligned}
$$

Jika diberikan kondisi awal $t=0$ dan $N(0)=N_{0}$ maka diperoleh nilai $c=\ln N_{0}$ sehingga bila nilai $c$ disubstitusikan ke dalam (3) akan menghasilkan,

$$
\begin{aligned}
& N(t)=e^{r t+\ln N_{0}} \\
& N(t)=e^{r t} e^{\ln N_{0}} \\
& N(t)=N_{0} e^{r t}
\end{aligned}
$$

Persamaan (4) merupakan bentuk solusi khusus dari model pertumbuhan eksponensial. Dari persamaan tersebut dapat dilihat jika nilai $r$ positif maka populasi akan meningkat secara eksponensial, sebaliknya jika nilai $r$ negatif maka populasi akan semakin punah.

\section{Model Pertumbuhan Logistik}

Model ini pertama kali diperkenalkan oleh matematikawan dan juga seorang ahli biologi berkebangsaan Belanda, yaitu Pierre Francois Verhulst pada tahun 1838, hal ini diakibatkan karena model pertumbuhan alami tidak cukup tepat untuk populasi yang cukup besar dan tempatnya terbatas sehinggga timbul hambatan karenanya padatnya populasi yang akan mengurangi populasi itu sendiri. Perubahan jumlah populasi setiap waktu merupakan salah satu penanda terjadinya pertumbuhan populasi yang dipengaruhi oleh jumlah kelahiran, kematian dan migrasi. Salah satu model pertumbuhan adalah model pertumbuhan kontinu khususnya model logistik. Model ini merupakan pengembangan dari model pertumbuhan eksponensial yang pertama kali dicetuskan oleh Maltus. [6]. Model pertumbuhan populasi logistik ini merupakan penyempurnaan dari model pertumbuhan eksponensial di atas. Model logistik digunakan karena pada kenyataan di alam bahwa besar kecilnya populasi bergantung pada kerapatannya, sehingga laju kelahiran dan laju kematian tidak konstan [6]. Bentuk yang paling sederhana untuk laju pertumbuhan relatif yang mengakomodasi asumsi ini adalah:

$$
\frac{1}{N} \frac{d N}{d t}=k\left(1-\frac{N}{K}\right)
$$

Kedua ruas dikalikan dengan $N$, maka diperoleh model untuk pertumbuhan populasi yang dikenal persamaan diferensial logistic;

$$
\frac{d N}{d t}=r N\left(1-\frac{N}{K}\right)
$$

Perhatikan dari persamaan (6) bahwa jika $N$ kecil dibandingkan dengan $K$, maka $N / K$ mendekati 0 dan $d N / d t \approx r N$. Namun, jika $N \rightarrow K$ (populasi mendekati kapasitas tampungnya), maka $N / K \rightarrow 1$, 
sehingga $\frac{d N}{d t} \rightarrow 1$. Jika populasi $N$ berada diantara 0 dan $K$, maka ruas kanan persamaan di atas bernilai positif, sehingga $\frac{d N}{d t} \rightarrow 1$ dan populasi naik. Tetapi jika populasi melampaui kapasitas tampungnya $(N>K)$, maka $1-\frac{N}{K}$ negatif, sehingga $\frac{d N}{d t}<0$ dan populasi turun. Solusi persamaan logistik dapat diperoleh melalui langkah-langkah berikut ini:

$$
\begin{aligned}
\frac{d N}{N\left(1-\frac{N}{K}\right)} & =r d t \\
\int \frac{d N}{N\left(1-\frac{N}{K}\right)} & =\int r d t \\
\ln N-\ln (K-N) & =r t+c \\
N & =\frac{K e^{r t+c}}{1+e^{r t+c}}
\end{aligned}
$$

Dari persamaan (7) jika kita memberikan nilai awal $t=0$ dan $N(0)=N_{0}$ kemudian disubstitusikan ke dalam (7) maka akan diperoleh nilai $c=\ln \left(N_{0} / K-N_{0}\right)$ selanjutnya nilai $c$ tersebut disubstitusikan kembali ke dalam persamaan (7), sehingga diperoleh solusi khusus dari model logistik seperti berikut,

Keterangan;

$$
\begin{aligned}
& N=\frac{K e^{r t+\ln \left(\frac{N_{0}}{K-N_{0}}\right)}}{1+e^{r t+\ln \left(\frac{N_{0}}{K-N_{0}}\right)}} \\
& N=\frac{K}{\left(\frac{K}{N_{0}} e^{-r t}-e^{-r t}+1\right)} \\
& N=\frac{K}{e^{-r t}\left(\frac{K}{N_{0}}-1\right)+1}
\end{aligned}
$$

$N$ : Jumlah populasi pada saat $t$

$N_{0}$ : Jumlah populasi awal saat $t=0$.

$K$ : Daya tampung (carrying capacity) dari suatu daerah untuk populasi.

$r$ : Laju pertumbuhan per kapita populasi.

$t$ : Waktu.

Persamaan (8) merupakan bentuk sederhana dari solusi khusus model logistik yang akan digunakan dalam melakukan proyeksi penduduk di Kabupaten Tulungagung dan Trenggalek. Menurut Lukman dan Kwardiniya penentuan nilai $K$ atau nilai carrying capacity diperoleh dari nilai limit dari $N(t)$ yaitu:

$$
N(t) \max =\lim _{t \rightarrow \infty} N(t)=\frac{a}{b}=\frac{N_{1}\left(2 N_{0} N_{2}-N_{2} N_{1}-N_{0} N_{1}\right)}{N_{0} N_{2}-N_{1}^{2}}
$$




\section{Formulasi Model}

Pada tahun 1798, Thomas Malthus membuat sebuah model pertumbuhan penduduk dasar dengan $N(t)$ menunjukkan populasi suatu spesies pada waktu dan dimisalkan $r=a$ merupakan laju pertumbuhan penduduk. Dari persamaan (2) diperoleh model: $\frac{d N(t)}{d t}=a N(t)$ persamaan ini adalah linear orde persamaan diferensial non-homogen yang dikenal sebagai hukum Malthus pertumbuhan penduduk. Dari persamaan (4) solusi dari persamaan di atas adalah $N(t)=N_{0} e^{a t}$.

Laju pertumbuhan penduduk yang terus meningkat dapat diperkecil dengan adanya faktor penghambat. Model pertumbuhan logistik adalah model pertumbuhan yang dibatasi oleh suatu faktor penghambat. Diturunkan model persamaan sebagai berikut:

$$
\frac{d N(t)}{d t}=a N(t)\left(1-\frac{N(t)}{M}\right)
$$

Jika $M=a / b^{\prime}$ maka diperoleh

$$
\frac{d N(t)}{d t}=a N(t)-b N^{2}(t)
$$

Dengan cara memisahkan variabel dan mengintegrasikan persamaan (9) diperoleh

$$
\frac{1}{a}(\ln N(t)-\ln (a-b N(t)))=t+C
$$

Jika diberikan syarat $t=0$ maka $N(0)=N_{0}$ diperoleh

$$
C=\frac{1}{a}\left(\ln N_{0}-\ln \left(a-b N_{0}\right)\right)
$$

Oleh karena itu persamaan (10) menjadi

$$
\frac{1}{a}(\ln N(t)-\ln (a-b N(t)))=t+\frac{1}{a}\left(\ln N_{0}-\ln \left(a-b N_{0}\right)\right)
$$

Didapatkan nilai $N(t)$ sebagai berikut [13]

$$
N(t)=\frac{a / b}{1+\left(\frac{a / b}{N_{0}}-1\right) e^{-a t}}
$$

Misalkan pada saat $t=1$ dan $t=2$ dari persamaan (12) diperoleh

$$
N_{1}=\frac{b}{a}\left(1-e^{-a}\right)=\frac{1}{N_{1}}-\frac{e^{-a}}{N_{0}} \text { dan } N_{2}=\frac{b}{a}\left(1-e^{-2 a}\right)=\frac{1}{N_{2}}-\frac{e^{-2 a}}{N_{0}}
$$

Dari persamaan (13) diperoleh

Sehingga

$$
\left(1+e^{-a}\right)=\frac{\frac{1}{N_{2}}-\frac{e^{-2 a}}{N_{O}}}{\frac{1}{N_{1}}-\frac{e^{-a}}{N_{0}}}
$$

$$
e^{-a}=\frac{N_{o}\left(N_{1}-N_{2}\right)}{N_{2}\left(N_{0}-N_{1}\right)}
$$


Persamaan (15) disubstitusikan ke dalam persamaan (13) sehingga didapatkan

$$
\frac{b}{a}=\frac{N_{o} N_{2}-N_{1}^{2}}{N_{1}\left(2 N_{0} N_{2}-N_{2} N_{1}-N_{0} N_{1}\right)}
$$

Dengan demikian nilai $K$ atau carrying capacity diperoleh dari nilai limit dari $N(t)$ adalah

$$
N(t)_{\max }=\lim _{t \rightarrow \infty} N(t)=\frac{a}{b}=\frac{N_{1}\left(2 N_{0} N_{2}-N_{2} N_{1}-N_{0} N_{1}\right)}{N_{0} N_{2}-N_{1}^{2}}
$$

\section{Data Jumlah Penduduk di Kabupaten Tulungagung Dan Trenggalek}

Untuk melakukan proyeksi penduduk di Kabupaten Tulungagung perlu dilakukan analisis perhitungan terlebih dahulu terhadap data jumlah penduduk di Kabupaten Tulungagung dan tahun-tahun sebelumnya. Hal ini dimaksudkan agar kita dapat mengetahui kecenderungan dan arah dari data yang kita gunakan. Jumlah data yang digunakan turut mempengaruhi keakuratan model dalam memprediksi keadaan populasi secara menyeluruh.

Dalam penelitian ini, data jumlah penduduk yang digunakan adalah data jumlah penduduk hasil sensus penduduk di Kabupaten Tulungagung dari tahun 2010 sampai tahun 2016 yang bersumber dari Badan Pusat Statistik (BPS) di Kabupaten Tulungagung. Berikut ini adalah tabel 1 yang menyatakan jumlah penduduk di Kabupaten Tulungagung dari tahun 2010-2016:

Tabel 1. Data jumlah penduduk di Kabupaten Tulungagung.

\begin{tabular}{lrr}
\cline { 2 - 2 } & Tahun & Jumlah Penduduk \\
\cline { 2 - 3 } & 2010 & 992.317 \\
2011 & 998.707 \\
2012 & 1.004 .711 \\
2013 & 1.009 .411 \\
2014 & 1.015 .974 \\
Sumber: BPS Kabupaten Tulungagung. & 2015 & 1.021 .190 \\
& 2016 & 1.026 .101 \\
\hline
\end{tabular}

Sumber: BPS Kabupaten Tulungagung.

Dari tabel 1 di atas terlihat bahwa sejak tahun 2010 - 2016 jumlah penduduk di Kabupaten Tulungagung mengalami kenaikan. Secara umum jika kita bandingkan jumlah penduduk pada awal tahun dan akhir tahun maka telah terjadi kenaikan jumlah penduduk di Kabupaten Tulungagung Provinsi Jawa Timur.

\section{Penyelesaian Model Logistik Pertumbuhan Penduduk di Kabupaten Tulungagung}

Untuk menentukan model logistik dari data jumlah penduduk di Kabupaten Tulungagung pada tabel 1 di atas, sebelumnya diasumsikan terlebih dahulu bahwa waktu $(t)$ yang diukur dalam tahun dan dimisalkan $t=0$ pada tahun 2010 maka syarat awal adalah $N(0)=992.317$. Selanjutnya adalah menentukan nilai carrying capacity atau kapasitas tampung yaitu $K$.

$$
N(t)_{\text {Max }}=\lim _{t \rightarrow \infty} N(t)=\frac{a}{b}=\frac{N_{1}\left(2 N_{0} N_{2}-N_{2} N_{1}-N_{0} N_{1}\right)}{N_{0} N_{2}-N_{1}^{2}}
$$

Dari tabel 1 diperoleh $t=0,1,2$ tahun 2010, 2011, 2012 dengan nilai $N_{0}, N_{1}, N_{2}$ masing-masing adalah

$$
N_{0}=992318, \quad N_{1}=9987072, \quad N_{2}=1004711
$$

Nilai $N_{0}, N_{1}, N_{2}$ disubstitusikan kepersamaan untuk mencari nilai Carrying Capacity sehingga diperoleh 
nilai yang membatasi penduduk di Kabupaten Tulungagung Provinsi Jawa Timur yaitu $(t)=\frac{a}{b}$, Selanjutnya perhitungannya adalah sebagai berikut:

$$
\begin{gathered}
N(t)_{\max }=\lim _{t \rightarrow \infty} N(t)=\frac{a}{b}=\frac{N_{1}\left(2 N_{0} N_{2}-N_{2} N_{1}-N_{0} N_{1}\right)}{N_{0} N_{2}-N_{1}^{2}} \\
=\frac{998.707(2 \times 992.317 \times 1.004 .711-1.004 .711 \times 998.707-992.317 \times 998.707)}{992.317 \times 1004.711-(998.707)^{2}} \\
K=1.089 .103,3
\end{gathered}
$$

Nilai $K$ dan $N_{0}$ didistribusikan ke solusi model logistik (8) sehingga diperoleh

$$
\begin{aligned}
& N=\frac{K}{e^{-r t}\left(\frac{k}{N_{0}}-1\right)+1} \\
& N=\frac{1.089 .103,3}{e^{-r t}\left(\frac{1.089 .103,3}{992.313}-1\right)+1} \\
& N=\frac{1.089 .103,3}{e^{-r t}(0,09754)+1}
\end{aligned}
$$

Selanjutnya dari persamaan (17) akan dicari model logistik yang dapat mewakili laju pertumbuhan penduduk di Kabupaten Tulungagung untuk $t=1$ pada tahun 2011 maka $N(1)=998.707$, jika didistribusikan ke persamaan (17) diperoleh

$$
\begin{aligned}
998.707 & =\frac{1.089 .103,3}{e^{-r}(0,09754)+1} \\
e^{-r}(0,09754) & =\frac{1.089 .103,3-998.707}{998.707} \\
r & =0,07480
\end{aligned}
$$

Nilai $r$ yang diperoleh didistribusikan kembali pada (17) maka menghasilkan

$$
N=\frac{1.089 .103,3}{(0,09754) e^{-(0,07480) t}+1}
$$

Untuk $t=2$ pada tahun 2012 maka $N(2)=1.004 .711$, jika disubstitusikan ke persamaan (17) diperoleh

$$
\begin{aligned}
1.004 .711 & =\frac{1.089 .103,3}{(0,09754) e^{-2 r}+1} \\
(0,09754) e^{-2 r} & =\frac{1.089 .103,3-1.004 .711}{1.004 .711} \\
r & =0,07472
\end{aligned}
$$

Jika nilai $r$ yang diperoleh disubstitusikan kembali pada (5.16) maka menghasilkan 


$$
N=\frac{1.089 .103,3}{(0,09754) e^{-(0,07472) t}+1}
$$

(Model II)

Untuk $t=3$ pada tahun 2013 maka $N(3)=1.009 .411$, jika disubstitusikan ke persamaan (17) diperoleh

$$
\begin{aligned}
1.009 .411 & =\frac{1.089 .103,3}{(0,09754) e^{-3 r}+1} \\
-3 r & =-0,21145 \\
r & =0,07048
\end{aligned}
$$

Jika nilai $r$ yang diperoleh disubstitusikan kembali pada (7) maka menghasilkan

$$
N=\frac{1.089 .103,3}{(0,09754) e^{-(0,07048) t}+1}
$$

(Model III)

Untuk $t=4$ pada tahun 2014 maka $N(4)=1.015 .974$, jika disubstitusikan ke persamaan (17) diperoleh

$$
\begin{aligned}
1.015 .974 & =\frac{1.089 .103,3}{(0,09754) e^{-4 r}+1} \\
(0,09754) e^{-4 r} & =\frac{1.089 .103,3-1.015 .974}{1.015 .974} \\
r & =0,07597
\end{aligned}
$$

Jika nilai $r$ yang diperoleh disubstitusikan kembali pada (17) maka menghasilkan

$$
N=\frac{1.089 .103,3}{(0,09754) e^{-(0,07597) t}+1}
$$

(Model IV)

Untuk $t=5$ pada tahun 2015 maka $N(5)=1.021 .190$, jika disubstitusikan ke persamaan (17) diperoleh,

$$
\begin{aligned}
1.021 .190 & =\frac{1.089 .103,3}{(0,09754) e^{-5 r}+1} \\
(0,09754) e^{-5 r} & =\frac{1.089 .103,3-1.021 .190}{1.021 .190} \\
r & =0,07661
\end{aligned}
$$

Jika nilai $r$ yang diperoleh disubstitusikan kembali pada (17) maka menghasilkan

$$
N=\frac{1.089 .103,3}{(0,09754) e^{-(0,07661) t}+1}
$$

(Model V)

Untuk $t=6$ pada tahun 2016 maka $N(6)=1.026 .101$, jika disubstitusikan ke persamaan (17) diperoleh 


$$
\begin{aligned}
1.026 .101 & =\frac{1.089 .103,3}{(0,09754) e^{-6 r}+1} \\
(0,09754) e^{-6 r} & =\frac{1.089 .103,3-1.026 .101}{1.026 .101} \\
r & =0,07717
\end{aligned}
$$

Jika nilai $r$ yang diperoleh disubstitusikan kembali pada (17) maka menghasilkan

$$
N=\frac{1.089 .103,3}{(0,09754) e^{-(0,07717) t}+1}
$$

(Model VI)

Dari hasil perhitungan diatas diperoleh hasil model logistik sebagai berikut:

1. Model Logistik I, dengan laju pertumbuhan relatifnya per tahun sekitar $7,5 \%$

2. Model Logistik II, dengan laju pertumbuhan relatifnya per tahun sekitar $7,5 \%$

3. Model Logistik III, dengan laju pertumbuhan relatifnya per tahun sekitar $7,05 \%$

4. Model Logistik IV, dengan laju pertumbuhan relatifnya per tahun sekitar $7,6 \%$

5. Model Logistik $V$, dengan laju pertumbuhan relatifnya per tahun sekitar $7,7 \%$

6. Model Logistik $\mathrm{VI}$, dengan laju pertumbuhan relatifnya per tahun sekitar $7,7 \%$

Selanjutnya akan dihitung jumlah penduduk di Kabupaten Tulungagung dari tahun 2010-2016 yang dihasilkan dari keenam model di atas,
1. Model Logistik I bentuk persamaannya $N=\frac{1.089 .103,3}{(0,09754) e^{-(0,07480) t}+1}$
2. Model Logistik II bentuk persamaannya $N=\frac{1.089 .103,3}{(0,09754) e^{-(0,07472) t}+1}$
3. Model Logistik III bentuk persamaannya $N=\frac{1.089 .103,3}{(0,09754) e^{-(0,07048) t}+1}$
4. Model Logistik IV bentuk persamaannya $N=\frac{1.089 .103,3}{(0,09754) e^{-(0,07597) t}+1}$
5. Model Logistik $\vee$ bentuk persamaannya $N=\frac{1.089 .103,3}{(0,09754) e^{-(0,07661) t}+1}$
6. Model Logistik VI bentuk persamaannya $N=\frac{1.089 .103,3}{(0,09754) e^{-(0,07717) t}+1}$

Berikut ini dalam tabel 2 memuat hasil jumlah penduduk berdasarkan lima model logistik di atas dari tahun 2010-2016.

Tabel 2. Perbandingan jumlah penduduk di Kabupaten Tulungagung antara hasil sensus dan hasil model.

\begin{tabular}{crrrrrrr}
\hline Tahun & Sensus & Model I & Model II & Model III & Model IV & Model V & Model VI \\
\hline 2010 & 992.317 & 992.313 & 992.313 & 992.313 & 992.313 & 992.313 & 992.313 \\
2011 & 998.707 & 998.710 & 998.700 & 998.353 & 998.810 & 998.856 & 998.856 \\
2012 & 1.004 .711 & 1.004 .717 & 1.004 .700 & 1.004 .040 & 1.004 .902 & 1.005 .004 & 1.005 .004 \\
2013 & 1.009 .411 & 1.010 .365 & 1.010 .346 & 1.009 .410 & 1.010 .618 & 1.010 .759 & 1.010 .759 \\
2014 & 1.015 .974 & 1.015 .651 & 1.015 .632 & 1.014 .459 & 1.015 .973 & 1.016 .144 & 1.016 .144 \\
2015 & 1.021 .190 & 1.020 .610 & 1.020 .591 & 1.019 .215 & 1.020 .992 & 1.021 .193 & 1.021 .193 \\
2016 & 1.026 .101 & 1.025 .269 & 1.025 .241 & 1.023 .689 & 1.025 .685 & 1.025 .917 & 1.026 .120 \\
\hline
\end{tabular}

Hasil yang diperoleh kemudian akan dibandingkan dengan data jumlah penduduk dari hasil sensus Kabupaten Tulungagung. Model terbaik adalah model yang menghasilkan data-data cukup dekat dengan data sebenarnya atau jika ditampilkan dalam bentuk grafik maka model terbaik adalah model grafik yang paling mendekati dengan grafik yang dihasilkan dari data sebenarnya. Dari tabel 2 dapat dilihat bahwa model I yang memiliki nilai paling mendekati dengan nilai sensus yang sebenarnya. Sehingga model I yang akan digunakan untuk memprediksi jumlah penduduk di Kabupaten Tulungagung pada tahun 2025. 
Jika perbandingan jumlah penduduk di Kabupaten Tulungagung antara hasil sensus dan hasil model pada tabel 2 ditampilkan dalam bentuk diagram batang, maka akan terlihat seperti di bawah ini.

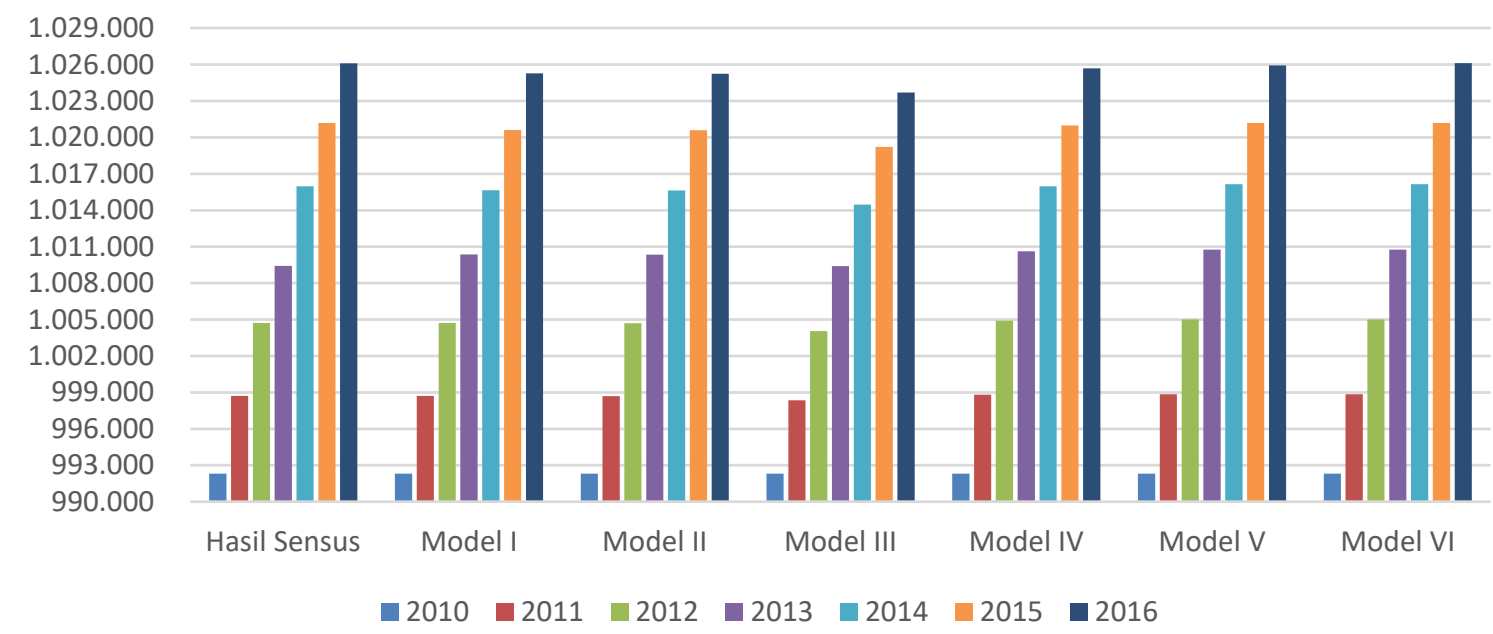

Gambar 1. Diagram batang jumlah penduduk di Kabupaten Tulungagung berdasarkan hasil sensus dan hasil model.

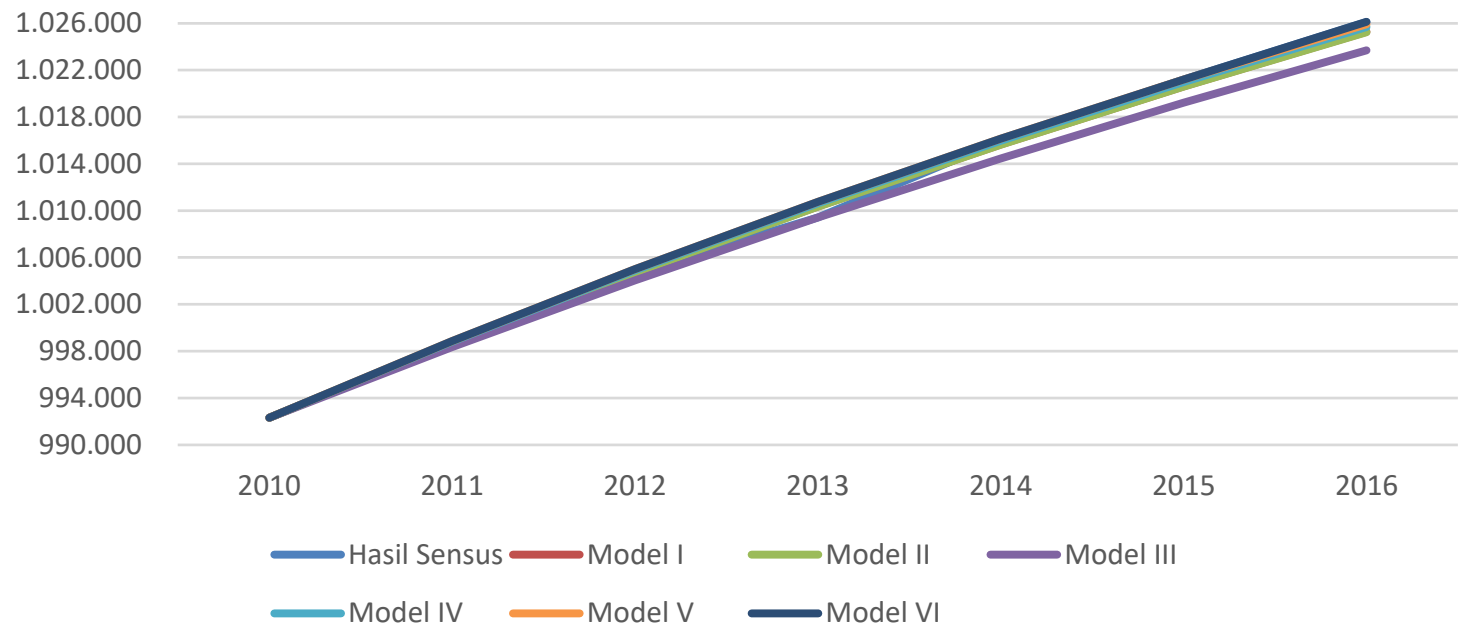

Gambar 2. Diagram garis jumlah penduduk di Kabupaten Tulungagung berdasarkan hasil sensus dan hasil model.

Berdasarkan jumlah penduduk yang dihasilkan oleh keenam model di atas, model logistik I memberikan hasil yang cukup mendekati hasil sensus dibandingkan model logistik II, III, IV, V dan VI. Selain itu keakuratan model logistik I cukup baik, hal ini dapat dilihat dari hasil jumlah penduduk di Kabupaten Tulungagung pada tahun 2010-2016 yang dihasilkan model logistik I hampir sama dengan hasil sensus penduduk 2010-2016. Dengan demikian dipilih model logistik I sebagai model final yang akan digunakan untuk memprediksi jumlah penduduk di Kabupaten Tulungagung pada sensus penduduk 2025.

Prediksi Jumlah Penduduk di Kabupaten Tulungagung Tahun 2025

Karena model logistik I digunakan untuk memprediksi jumlah penduduk di Kabupaten Tulungagung pada tahun 2025, maka persamaan modelnya adalah:

$$
N=\frac{1.089 .103,3}{(0,09754) e^{-(0,07480) t}+1}
$$


Dari model di atas laju pertumbuhan relatif penduduk di Kabupaten Tulungagung adalah 7,48\% per tahun. Selanjutnya untuk memprediksi jumlah penduduk pada tahun 2025 diambil $t=15$ disubstitusikan ke dalam model logistik 1 diatas peroleh:

$$
N=\frac{1.089 .103,3}{1,03176}=1.055 .578
$$

Dari hasil perhitungan di atas diperoleh jumlah penduduk di Kabupaten Tulungagung pada tahun 2025 yang dihasilkan model logistik adalah 1.055.578 jiwa.

\section{Proyeksi Penduduk di Kabupaten Tulungagung dengan MAPLE}

Berikut ini akan diberikan gambar proyeksi untuk jangka waktu yang akan datang penduduk di Kabupaten Tulungagung menggunakan model logistik dengan pengambilan $t=0 . .15$. Dari grafik pertumbuhan dapat dilihat bahwa jumlah penduduk di Kabupaten Tulungagung dari tahun ke tahun terus mengalami kenaikan.

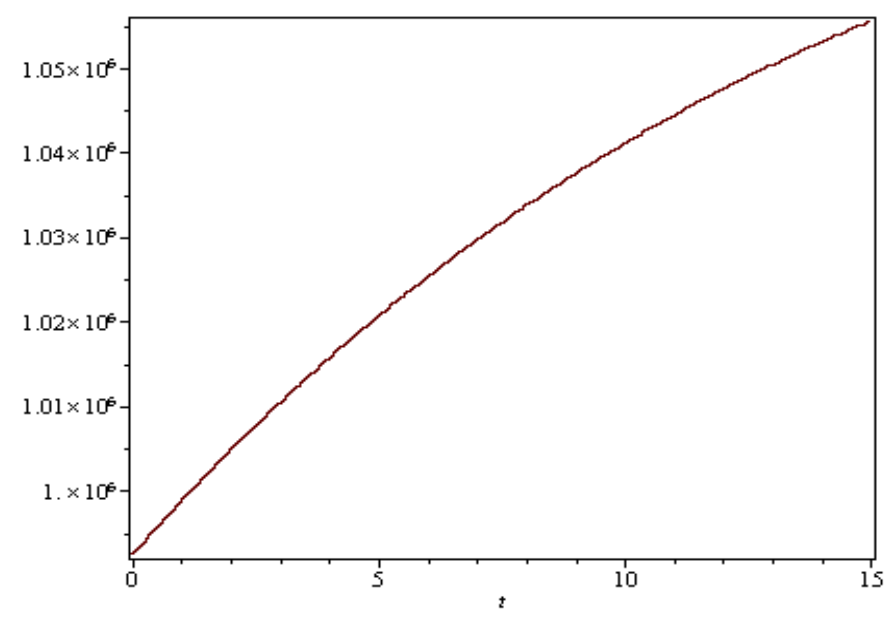

Gambar 3. Grafik pertumbuhan verhulst $(t=0 . .15)$.

Berikutnya akan diberikan proyeksi pertumbuhan penduduk dengan pengambilan waktu $t=0 . .200$. Dari grafik dapat dilihat bahwa untuk jangka waktu yang akan datang penduduk di Kabupaten Tulungagung tidak akan melebihi kapasitas tampung (carring capacity) tetapi mendekati kapasitas tampungnya.

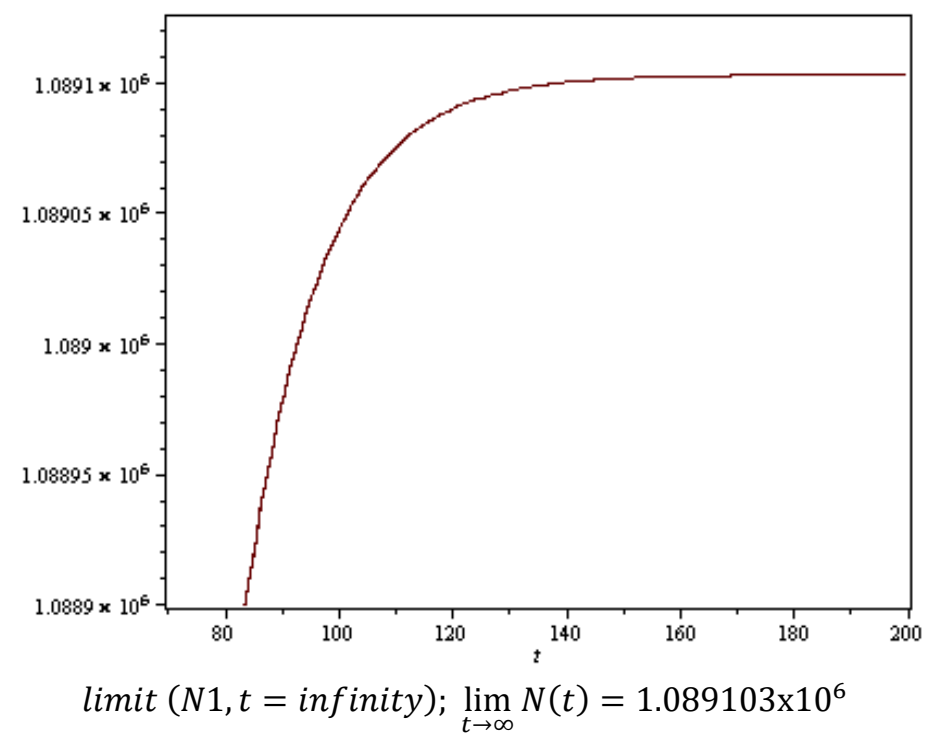

Gambar 4. Grafik pertumbuhan verhulst $(t=0 . .200)$. 


\section{Kesimpulan}

Berdasarkan pembahasan yang telah diuraikan sebelumnya maka dapat disimpulkan beberapa hal:

1. Besarnya nilai carrying capacity yang membatasi penduduk di Kabupaten Tulungagung adalah sebesar 1.089.103,3 jiwa.

2. Laju pertumbuhan intrinsik penduduk di kabupaten Tulungagung dengan menggunakan Model pertumbuhan logistik adalah sebesar $r=0,07480$.

3. Jumlah penduduk di Kabupaten Tulungagung pada tahun 2025 dari hasil estimasi menggunakan model pertumbuhan logistik adalah sebesar 1.055.578 jiwa.

4. Proyeksi jumlah penduduk di Kabupaten Tulungagung lebih tepat menggunakan model logistik I karena nilainya yang mendekati hasil sensus. Berdasarkan grafik menggunakan MAPLE maka jumlah penduduk di Kabupaten Tulungagung tidak akan melebihi nilai kapasitasnya pada jangka waktu yang akan datang akan tetapi mendekati nilai kapasitas tampung $(K)$.

\section{Referensi}

[1] Badan Pusat Statistik. 2013. Proyeksi Penduduk Indonesia (Indonesian Population Projection) 2010-2035, Jakarta.

[2] Brauer \& Chavez, Castillo. 2001. Mathematical Models In Population Biology and Epidemiology. Springer

[3] Creswell, J. W. (2010). Research design: pendekatan kualitatif, kuantitatif, dan mixed. Yogjakarta: PT Pustaka Pelajar.

[4] Finizio, N. dan G. Ladas. 1988. Persamaan Diferensial Biasa Dengan Penerapan Modern. Erlangga. Bandung.

[5] Hathout, D. 2013. Modeling Population Growth: Exponential and Hyperbolic Modeling. Applied Mathematics, 4(2), pp: 299-304

[6] J. Purcell, Edwin \& Varberg, Dale. 1987. Kalkulus dan Geometri Analitis, jilid 2, edisi kelima. Penerbit Erlangga, Jakarta.

[7] Miles, B. Mathew dan Michael Huberman. 1992. Analisis Data Kualitatif Buku Sumber Tentang Metode-metode Baru. Jakarta: UIP.

[8] Moleong, L. 2014. Metodologi Penelitian Kualitatif. Edisi Revisi. Bandung: PT Remaja Rosdakarya.

[9] Ofori.T, Ephraim.L dan Nyarko.F. 2013. Mathematical Model of Ghanas Population Growth. International Journal of Modern Management Sciences, 2(2), pp: 57-66

[10] Rahardi, Rustanto, dkk. 2003. Persamaan Diferensial Biasa. Jurusan Matematika, fakultas MIPA, Universitas Negeri Malang.

[11] Stewart, James. 2009. Kalkulus. Penerbit Salemba Teknika. Jakarta.

[12] Sugiyono. 2011. Metode Penelitian Kualitatif, Kuantitatif, dan R\&D, Bandung: Alfabeta.

[13] Supama, dkk. 2003. Kalkulus 1. Fakultas Matematika dan ilmu pengethuan alam. Universitas Gadjah Mada.

[14] Tarumingkeng, R. C. 1994. Dinamika Populasi (Kajian Ekologi Kuantitatif), Pustaka Sinar Harapan, Jakarta. 